\title{
Math Education in Intercultural Contexts: a logical-mathematical interpretation for duality Kaingang Kamé-Kairu
}

\section{Educação Matemática em Contextos Interculturais: uma interpretação lógico-matemática para a dualidade Kaingang Kamé-Kairu}

\author{
Luci dos Santos Bernardi ${ }^{1}$ \\ Jorge Alejandro Santos ${ }^{2}$
}

\begin{abstract}
'Universidade Regional Integrada do Alto Uruguai e das Missões (URI), Programa de Pós-Graduação em Educação, Frederico Westphalen, RS, Brasil. Corresponding Author: lucisantosbernardi@gmail.com

${ }^{2}$ Universidad Nacional de Hurlingham (UNaHur), Consejo Nacional de Investigaciones Científicas y Técnicas (Conicet), Buenos Aires, Argentina.
\end{abstract}

\begin{abstract}
The aim of this paper is to present the results of research carried out in a Mathematics and Science training program for indigenous teachers of the Kaingang ethnic group by the Unochapecó in the municipality of Chapecó, Santa Catarina, Brazil. Based on the paradigm of ethno mathematics, one of the objectives of the program is to look for relations between traditional indigenous thinking and classical mathematics. We propose an analogy between logical-mathematical binary calculation systems and the Kaingang thought system expressed in its social organization and supported by two opposite and complementary dual categories: Kamé-Kairu. Our hypothesis postulates a certain similarity between the binary logic used for example, in logical circuits, and the binary system with which the traditional Kaingang culture encodes its social, natural, and even supernatural world. The binary pair Kaingang, KaméKairu serves to codify relations of kinship, exchange, and alliances of the tribe, as well as the natural world that surrounds them. The analogy formulated provides interesting information for mathematical and scientific education in intercultural contexts.
\end{abstract}

Palavras-chave: Mathematics teaching; Indigenous education; Binary code; Interculturality; Ethno mathematics.

Resumo: O objetivo deste artigo é apresentar os resultados de uma pesquisa realizada em um programa de formação em Matemática e Ciências para professores indígenas da etnia Kaingang pela Unochapecó, no município de Chapecó, Santa Catarina, Brasil. Baseado no paradigma da etnomatemática, um dos objetivos do programa é buscar relações entre o pensamento indígena tradicional e a matemática clássica. Propomos uma analogia entre os sistemas de cálculo binário lógico-matemáticos e o sistema de pensamento Kaingang expresso em sua organização social e apoiado por duas categorias opostas e complementares: KaméKairu. A hipótese postula certa semelhança entre a lógica binária usada, por exemplo, nos circuitos lógicos, e o binarismo com o qual a cultura Kaingang tradicional codifica a relação de parentesco, troca e alianças da tribo, bem como o mundo natural que os rodeia. A analogia proposta pode fornecer informações interessantes para a educação matemática e científica em contextos interculturais.

Keywords: Ensino de matemática; Educação indígena; Código binário; Interculturalidade; Etnomatemática.

Recebido em: 03/04/2019

Aprovado em: 26/05/2020 


\section{Introduction}

The aim of this article is to propose an analogy between logical-mathematical binary calculation systems and the Kaingang ${ }^{1}$ thought system as expressed in its social organization, which is supported by two opposite and complementary dual categories: Kamé-Kairu².

The Kaingang people are traditionally divided into two exogamic and patrilineal parts. This order is founded upon a creation myth that holds that two mythological brothers called Kamé and Kairu, emerged from the depths of the earth to create the tribe with their respective clans, and everything else on earth (NIMUENDAJU, 1986, p. 87) except for fire, water, and air. Therefore, the tribe organizes its reality based upon these two opposite and complementary categories. The categories are opposite and complementary in the sense that, one cannot exist without the other.

The hypothesis of this paper originates from the work carried out at the Community University of the Chapecó Region (Unochapecó). The university, in addition to the regular undergraduate and graduate courses, organizes a training course for Indigenous Intercultural Teacher within the indigenous territory of Toldo Chimbangue, which is located in the Chapecó municipality, Santa Catarina, Brazil.

The Graduate Education Program of Unochapecó has two lines of research. One focuses on social inequalities, sociocultural diversity, and educational practices. The other focuses on teacher training, knowledge production and pedagogical processes. Both lines work closely with the experience of training indigenous teachers, and address issues such as the incorporation of new information and communication technologies in the education of children and young adults.

In terms of mathematics education, we work with the paradigm of ethno mathematics which investigates traditional cultures, practices, tasks, relations, techniques that express knowledge equivalent to school mathematics. The term ethnomathematics was coined by the Brazilian mathematician Ubiratan D'Ambrosio, from an analysis of the relations between mathematical knowledge and cultural context (LÓPES BELLO, 1996). From our point of view, it is essential for an intercultural education to establish relations between traditional wisdom and school mathematics.

Working in these areas, we perceive certain similarity between the binary logic used to communicate with computers and the binary logic with which traditional culture Kaingang encodes its entire social, natural, and even supernatural world. Logic circuits can only receive two kinds of inputs (on / off) that are translated as 0 and 1.This coding is based on the Boolean algebra that defines the logical operations of conjunction, inclusive disjunction and negation algebraically.

On the other hand, the Kaingang binary encodes various relationships, including kinship, exchange, and tribe alliances as well as the natural and supernatural world. They also express geometric-mathematical intuitions. Kamé is long or stretched - in

\footnotetext{
'Kaingan, in agreement with the indigenous communities of the region, is the expression in Portuguese for Kaingáng or Kanhgán in the indigenous language.

${ }^{2}$ In the writings about the Kaingang, we find variations such as: Kairu, Kanhuru, Kaĩru, Kanieru, Kadnyerú, Kañerú and Kaijru. We use the Kairu nomination, following the nomenclature used in the community of Toldo Chimbangue Village.
} 
other words, taller than it is wide - whereas Kairu is rounded with similar proportions between width and length. According to Veiga (2000, p. 79, our translation):

The Kamé are related to the sun, persistence, permanence, hardness, low places, and long objects. The Kaîru are related to the moon, the dew, the humidity, the moving, the agility, to high places and to low and round objects. Unity is the sum of these principles.

The duality also serves as a criterion of classification of the natural world. For example, the araucaria ( $f a \tilde{g}$ ) that grows in the Atlantic Forest is clearly Kamé due to its height, whereas the cedar (fwó), which is shorter and wider is Kairu - as an example: Kamé: sun $=$ rõ; paca $=$ kokomé; deer $=$ kémbê; parrot $=$ kéinkrĩri $;$ wild cat $=$ ngrudn. Kairu: moon = kysõ; coati = xê; armadillo = fẽntfẽn; river wolf = fagn-ndo; toucan = ngrũ; catfish =rig-mbâg (VEIGA, 2000). Finally, Kamé and Kairu can be represented with 'marks' painted on the body. Strikingly, these marks bear graphic resemblance to the Arabic numerals for zero and one. Kamé is represented through a long and black vertical line: I (rã tei or rã joj). A rounded point represents Kairu, which is generally red: • (rã rôr or rã kutu). Usually the body paintings correspond to two vertical lines and three points, respectively (Figure 1).

Figure 1 - Clan Halves

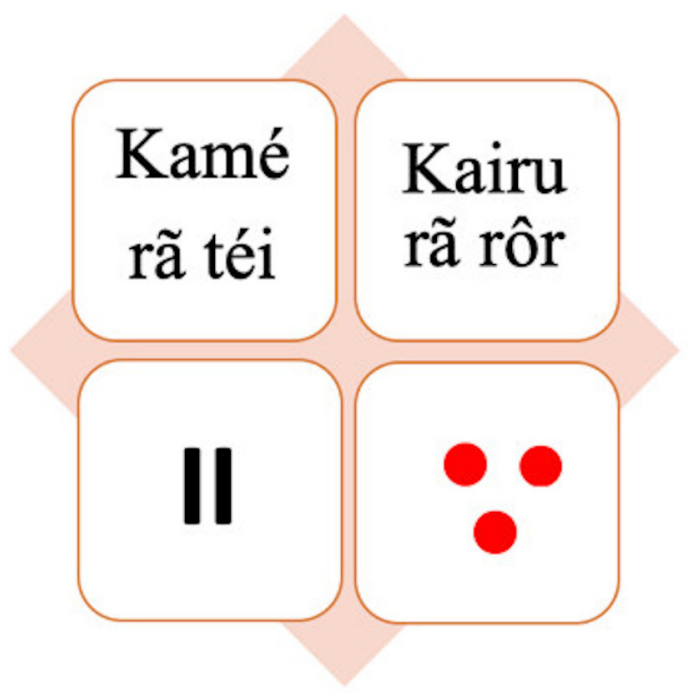

Source: Prepared by the authors.

The formal analogy is not difficult to perceive in principle. Our analogy allows connecting the perceived primitive logic categories of a hunter-gatherer society with the perceived sophisticated logic categories of the Western culture.

The aim of this paper is to analyze this analogy under the hypothesis that, if it is demonstrated, it could provide information about some of the most basic and common forms of logical thought.

This information is important in a context of intercultural education. It allows us to establish links between traditional ways of thinking and Western mathematics. It is always easier to learn what is familiar than from what is unknown. Our hypothesis allowed us to achieve one of the requirements of indigenous intercultural education in the state of Santa Catarina: to incorporate traditional knowledge and Western mathematics in the area of mathematics teaching. This has additional benefits, such as a greater appreciation 
of traditional culture and an increase in self-esteem among indigenous populations, since traditional knowledge would be incorporated into the mathematics and science curriculum (BERNARDI; SANTOS, 2018).

The article begins by presenting the Kaingang culture and its particular way of codifying reality. Next, we explore the scope of our proposed similarity between the Kaingang duality and mathematical binary system. The implications of this similarity will be discussed in the conclusion.

\section{The Kaingang Societies}

The Kaingang constitute the main Jê society of Southern Brazil and can be found from southern São Paulo to Rio Grande do Sul, including in the states of Paraná and Santa Catarina.

The Jê, along with the Bororó, are considered by some researchers as dialectical societies (MAYBURY-LEWIS, 1979), which are characterized by forming social orders based on bipartition between two groups - us and others - but also: "[...] this bipartition of society is part of a world view which insists on a bipartition of the total universe" (MAYBURY-LEWIS, 1979, p. 231). In most Jê societies, the principle of opposition establishes a distinction between close/distant, consanguineous/related, humans/animals, humans/ spirits (VEIGA, 1994, p. 8).

The Jê are characterized by ordering social, natural, and supernatural worlds through a partition between two opposing and complementary elements. The opposite elements vary in the different Jê societies. Some, like the Krahô, even have several different pairs of halves applicable to different functions (VEIGA, 1994).

The Kaingang society differs from other Jê in that they only have a pair with which they codify part of reality. It regulates exogamy, that is, kin relationships and, serves as a principle of social organization because it prescribes relations of exchange and alliances. It is also the basic class with which natural world - animals and plants, for example - are sorted and classified. Finally, these categories have a very important role in the funerary rites of Kikikoi with which the Kaingang dismiss their dead. Therefore, the duality regulates the world of the supernatural.

The worldview of this ethnic group is organized around the pair of complementary opposites Kamé / Kairu. This fundamental duality is expressed in many aspects of traditional culture. For example, in the structure and design of basketry the designs and drawings respond to the Kamé mark if they are vertical or elongated, and to Kairu if they are rounded (SUFIATTI; BERNARDI; DUARTE, 2013).

\section{Logical-Mathematical Analysis of the Kamé-Kairu Duality}

It is relatively simple to demonstrate that opposition supposes the logical principles of identity, of excluded middle and non-contradiction. First, we must clarify something regarding the method of logical (or ethno-logical) analysis. We will not argue that, in fact, the Kaingang explicitly formulated any of the three cited logical principles, because they did not. Rather, we propose that their structures of social and family organization, and therefore the structures of thought according to which they formulate them, show that they use these principles without any theoretical formulation. 
We will add a new element regarding how Kamé-Kairú duality works in the Kaingang social order. Membership in the exogamic groups in which the tribe is divided is inherited patrilineal; the children belong to the same group as the father. There is a word to name someone who does not belong to the same clan half: lambré. This word can refer to a related member of the other half with whom it is possible to marry because they are not consanguineous. But, lambré is also used by the husband to refer to the brothers of the wife and vice versa by the brothers of the wife to refer to his brotherin-law. The brothers-in-law establish relations of collaboration and cooperation that are the foundation of the traditional Kaingang social organization. In any sense of the word, lambré is used to name the one that does not belong to the same half and, therefore, it is possible to establish relations of affinity or cooperation. In a certain way, it means opposite and complementary.

Logically, we can say that if a Kaigang is Kairu, his lambré cannot be Kairu, and then he/she is necessarily Kamé. Therefore, if a member of the group is not Kairu then he (or she) is Kamé $\left(\sim^{\bullet}=\mathrm{I}\right)$. And conversely if a member of the group is Kamé then his lambré cannot be Kamé, thus his lambré is Kairu $(\sim \mathbf{I}=\bullet$ ). If we apply the principle of transitivity this is the result: $\left(\sim\left(\sim^{\bullet}\right)=^{\bullet}\right)$ or $\left(\bullet^{\bullet}=\bullet\right)$. Additionally, Kairu is necessarily different from Kamé: $(\bullet \neq \mathbf{I})$ or $\left(\bullet^{\bullet} \sim \bullet\right)$. This expresses what we call in logics the identity principle $A=A$, and $A \neq$ not $A$ or using the Kaingang marks $(\bullet=\bullet)$ and $(\bullet \neq \sim \bullet)$.

Both natural objects and members of the tribe are classified within the clan halves. Therefore, something or someone is Kamé or Kairu: $(\bullet \vee \mathrm{I})$. Or, transitively, is Kairu or is not Kairu $(\bullet \vee \sim \bullet)$. In logic terms, the principle of excluded middle: something is $A$, or is not $A,(A \vee \sim A)$. There is no other possibility.

Finally, if someone belongs to the middle Kairu cannot belong to the half Kamé, someone or something cannot be Kairu and not Kairu, $\sim(\bullet \sim \bullet)$. That is, the principle of non-contradiction $\sim(A . \sim A)$ is stated in an equivalent manner.

From the presented reasoning, we can verify that the binary categories with which the social and natural Kaingang order is established $(\bullet, I)$, respond to the logic principles of identity, non-contradiction, and excluded middle.

But to work with these principles it is necessary to operate with the logical functions of: equivalence $(=)$ to formulate the principle of identity, negation $(\sim)$, disjunction (v) for the excluded third party, and conjunction (.) for the principle of non-contraction. To affirm that something is Kamé or not, it is necessary to operate with the inclusive disjunction function that in English corresponds to the word or, and with the negation function that correspond to the word not. In Kaingang these functions are fulfilled by the terms ẽn and tữ, respectively.

Kaingang thought shows to operate with these logical functions, although obviously it does not define them theoretically or formalize them. This brings us to our next point: an analysis of the binary categories Kamé-Kairu with the basic concepts of the Boolean algebra.

\section{Algebraic Analysis of Boolean Functions}

Three of the logical functions cited in the previous section can be expressed with primitive operations of the Boolean algebra: negation, inclusive disjunction, and conjunction. Inclusive disjunction corresponds to the addition of algebra, whereas 
conjunction can be referred to as logical multiplication. We will discuss only the basic elements and definitions of algebra that are necessary for analyzing the proposed analogy.

A Boolean function is defined as one whose variables are binary and are joined by the operators of the Boolean algebra, logical addition (+), logical product (.) or logical negation ( ). This is relevant because it is used for basic communication with a computer, since electronic circuits respond to its logical-mathematical scheme. From these logic circuits, machines can receive and operate information.

We will present the first operator of the Boolean logic (+) (Table 1). In terms of propositional logic, it is equivalent to the inclusive disjunction function that is generally represented by the sign (v). In Spanish, this function is fulfilled by the word $o$, in English by or and in Kaingang by ẽn ${ }^{3}$ :

Table 1 - Logical addition

\begin{tabular}{|c|c|c|}
\hline$A$ & $B$ & + \\
\hline 0 & 0 & 0 \\
\hline 0 & 1 & 1 \\
\hline 1 & 0 & 1 \\
\hline 1 & 1 & 1 \\
\hline
\end{tabular}

Source: Prepared by the authors.

To represent logical functions, 0 is interpreted as false (also called logical zero) and 1 as true. Its logical equivalence in a circuit of switches is a circuit of two switches in parallel. For the addition to be 0 (false), both must be off $(0,0)$, otherwise it will give 1 (true) as a result. This fits one of the logical functions of the or in English (Figure 2).

Figure 2 - Logical disjuntion

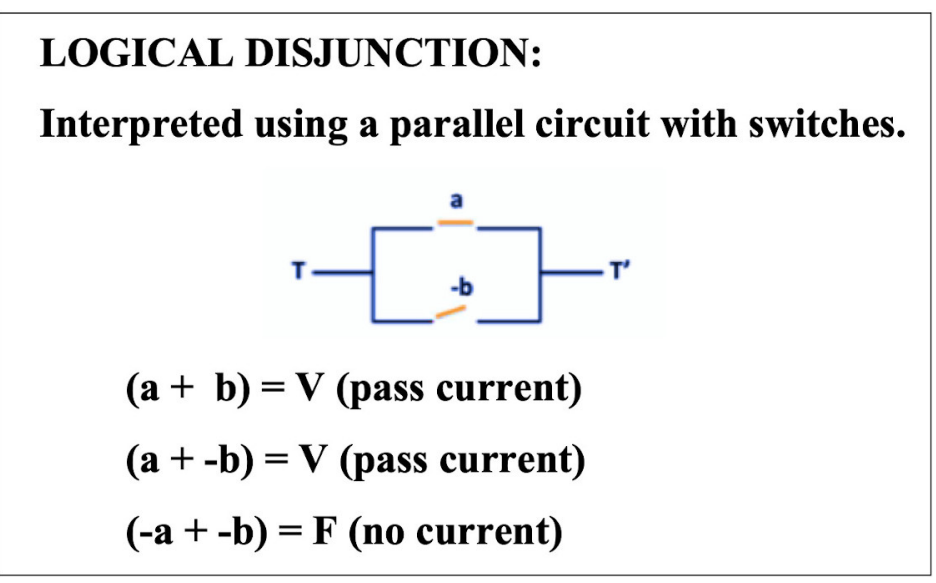

Source: Prepared by the authors.

\footnotetext{
${ }^{3}$ The Kaingang culture did not develop writing. However, since the first Jesuit contact in 1628 , there were multiple attempts to ascribe graphics for language to translate it. The linguist Ursula Gojtéj Wiesemann did an excellent job of both bibliographic and field studies to create a Kaingang-Portuguese dictionary (WIESEMANN, 2011). In this article we use this dictionary, but we also work directly with the Kaingang language teachers, who are direct informants of the use of the language in the territory. There are at least five Kaingang dialects, so there are differences between the graphics proposed by the linguist and the different dialects found in different regions and villages.
} 
The logical product operation (Table 2) corresponds to conjunction. In Spanish, the most common way of representing this function is with the word $y^{\prime}$ with and in English, and with kar, hã ra or ge ra in Kaingang ${ }^{4}$ :

Table 2 - Logical product

\begin{tabular}{|c|c|c|}
\hline$A$ & $B$ & $\bullet$ \\
\hline 0 & 0 & 0 \\
\hline 0 & 1 & 0 \\
\hline 1 & 0 & 0 \\
\hline 1 & 1 & 1 \\
\hline
\end{tabular}

Source: Prepared by the authors.

This logic operation in switches is equivalent to a series circuit of two switches, therefore it results in 1 (true) only when both are connected $(1,1)$ (Figure 3 ).

Figure 3 - Logical conjunction

\section{LOGICAL CONJUNCTION:}

Interpreted with a circuit in series of two switches.

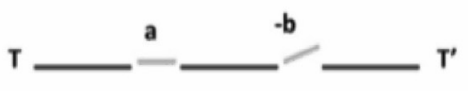

$\mathbf{V}(\mathbf{a} \cdot \mathbf{b})=\mathbf{V}$ (pass current)

$V(\mathbf{a} \cdot-\mathbf{b})=\mathbf{F}$ (no current)

Source: Prepared by the authors.

The function of negation (Table 3 ) has the same name in formal logic as in this algebra and corresponds to the no in Spanish, the not in English, and the tữ in Kaingang:

Table 3 - Negation

\begin{tabular}{|c|c|}
\hline$A$ & $\sim$ \\
\hline 0 & 1 \\
\hline 1 & 0 \\
\hline
\end{tabular}

Source: Prepared by the authors.

An inverter switch is equivalent to this operation in electronic circuits (Figure 4).

${ }^{4}$ They are translated as: and, but, however, and correspond closely to conjunctions in English. 
Figure 4 - Negation

\section{THE NEGATION:}

Interpreted with an inverted circuit.

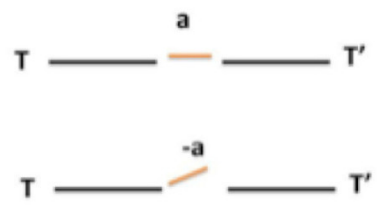

$\mathbf{V}(\mathbf{a})=\mathrm{V}$ (pass current)

$V(-\mathbf{a})=F($ no current)

Source: Prepared by the authors.

From these three primitive operations others more complex operations can be derived. For example, in combining a negation with a logical addition we can obtain the conditional function (Table 4). In Spanish, this is represented by "si... entonces", in English by "If ... then" and by sir, tugrõn or tỹ ${ }^{6}$ in Kaingang:

Table 4 - Material implication

\begin{tabular}{|c|c|c|}
\hline$A$ & $B$ & $\square$ \\
\hline 0 & 0 & 1 \\
\hline 0 & 1 & 1 \\
\hline 1 & 0 & 0 \\
\hline 1 & 1 & 1 \\
\hline
\end{tabular}

Source: Prepared by the authors.

When represented in a circuit of switches, the function is composed of two switches in parallel (logical addition or inclusive disjunction) being the first inverse (negation of the first disjunction). The result is 0 only when $a$ is 1 (since it is a reverse function it is disconnected) and $b$ is 0 (Figure 5). In terms of formal logic, it is equivalent to the conditional function that is only false when the antecedent $a$ is true (1) and the consequent false $b(0)$.

Figure 5 - Material Implication

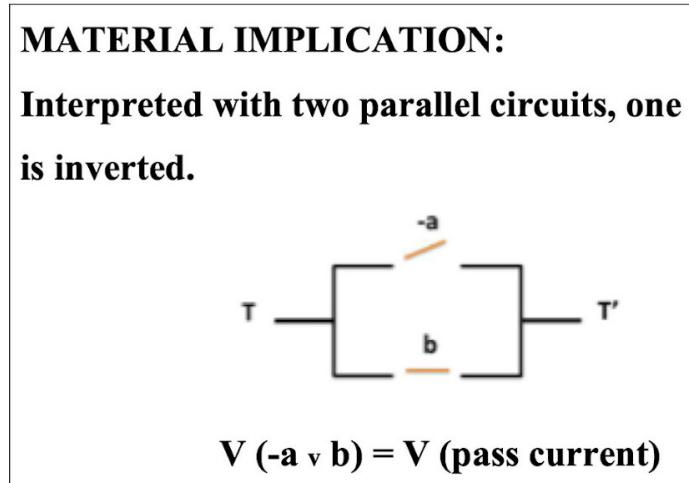

Source: Prepared by the authors.

${ }^{6}$ These words translate as: then, because of or on condition of, and by respectively, corresponding closely to the forms of English with which conditional relations are established. 
Given what we have presented so far, we can logically state that the necessary elements to operate in an algebraic or logical system are present in Kaingang culture. As in Boole's algebra or as in propositional logic, Kaingang culture contains two binary elements and three logical operations. This does not mean that Kaingang culture developed this system on purpose; rather the conditions of logic possibility are present.

An example can clarify our conclusion. In the traditional Kaingang culture there are only five numbers: pir, régre, tãgtu, venhlãgra and pénkar (ANHAIA, 2013). These are equivalent to $1,2,3,4$, and 5 . They also have some expressions that mean many or all (tikar), which is typical of hunter-gatherer cultures that do not need more than these concepts to efficiently organize their survival. However, the Kaingang also have the pénkar-pénkar, meaning 10. This means that they have $1,2,3,4,5$, and 10 , but no $6,7,8$, or 9. While this may appear odd, the logical-mathematical explanation is rather simple. Ten is equivalent to two groups of five (pénkar-pénkar), therefore they do not need to have $6,7,8$ and 9 to count 10 elements. With the successive repetition of this operation they could count infinite numbers. They have not done this, and they probably will not do so in the future, because the operation has no meaning for the traditional Kaingang organization.

We believe that the Kaingang thought expressed in its social order and in the way of classifying the world with the opposition $(\bullet, I)$, is evidence of possessing the necessary logical conditions for the development and understanding of systems similar to the Boolean algebra. This information was interesting for our project of mathematics education in an intercultural context. It allowed us to establish different parallels between traditional thinking and modern mathematics. Mathematics education can use traditional knowledge to facilitate the understanding of classical mathematical concepts.

We have other evidence that served to confirm our belief and that we will present in the next section.

\section{The Function Iambré}

There is one more element that serves as evidence. The lambré function in the Kaingang culture can be represented with an operator defined in Boolean algebra. Recall that lambré refers to a relationship of affinity, whether for marriage or for relations of cooperation and alliance. In a general sense, lambré is a complementary opposite. Given any two members of the Kaingang community (defined below as $a$ and $b$ ) there may be a lambré relationship $(\bullet \mathbf{l})$ if:

Table 5 - lambré

\begin{tabular}{|c|c|c|}
\hline$A$ & $B$ & $\bullet \mathbf{I}$ \\
\hline 0 & 0 & 0 \\
\hline 0 & 1 & 1 \\
\hline 1 & 0 & 1 \\
\hline 1 & 1 & 0 \\
\hline
\end{tabular}

Source: Prepared by the authors. 
Therefore, there is affinity ( 1 ) when there are opposite values $(1,0)$ or $(0,1)$ and there is no affinity when the values are the same $(0,0)$ or $(1,1)$ (Table 5$)$. The affinities belong to opposing clan halves, and, consequently, there is no logically possible affinity between those belonging to the same half.

This algebraic operation corresponds to the exclusive disjunction in formal logic that is a function defined from the primitive negation and conjunction (logical multiplication): $(\mathrm{a} w \mathrm{~b})=(\mathrm{a} . \sim \mathrm{b}) \vee(\sim \mathrm{a} . \mathrm{b})$. In an electronic circuit, this is equivalent to two linear circuits in parallel; the first of which has a normal switch followed by an inverse one and the remaining one inverse followed by a normal one, so that it is only 1 when $a$ is 1 and $b$ is 0 (thus inverse in the first linear circuit), or when $a$ is 0 (inverse therefore in the second linear circuit) and $b$ is 1 (Figure 6).

This demonstrates that at least one central aspect of Kaingang organization can be represented through Boolean algebra and even from an electrical circuit. Just as the electronic circuit assumes a logical and algebraic operation, the lambré function also carries it implicitly.

Figure 6 - Exclusive disjuntion

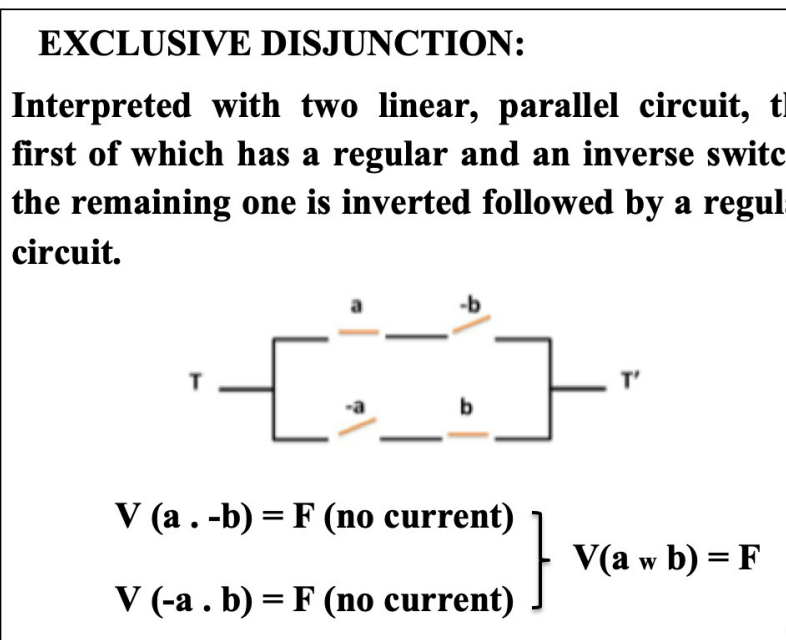

Source: Prepared by the authors.

We believe that we have sufficiently demonstrated the plausibility of the analogy presented in the introduction. There is a clear logical similarity between the binary thinking of the Kaingang people, and the binary logic used to communicate with the machines expressed in electronic circuits. Next, we turn to the implications of this hypothesis for mathematics education.

\section{Relevance of the Analogy for Education in an Intercultural Context}

As we pointed out in the introduction, we believe that the paradigm of ethno mathematics is very useful for the teaching of mathematics in an intercultural context.

Fundamental to the concept of ethno mathematics is to understanding culture as a set of compatible behaviors and shared knowledge (D'AMBROSIO, 2005). Thus, in the same culture, individuals elaborate the same explanations and use the same material and intellectual instruments in their daily life: 
These instruments are manifested in mannerisms, in skills, in the arts, in techniques, in the ticas of dealing with the environment, of understanding and explaining facts and phenomena, of teaching and sharing it. This is the matema of the group, of the community (etno). That is ethno mathematics (etno-matema-ticas). (D'AMBRÓSIO, 2005, p. 35, our translation and highlights).

The paradigm of ethno mathematics proposes to establish a dialogue between institutionalized mathematics and traditional mathematics. In other words, dialogue between the dominant Western tradition and the cognitive style, practices, and diverse behaviors of the indigenous peoples.

Our work tries to establish the dialogue proposed by ethno mathematics with the traditional wisdom of the Kaingang community. This approach has several pedagogical advantages in teaching mathematics.

Firstly, this correlation has important pedagogical implications, as it can establish a link between the knowledge a student already possesses, and that which the student is learning in school. Learning rooted in already-held knowledge is much easier than beginning from utterly unknown concepts. In the case of indigenous education, this implies connecting two different cultural traditions: mathematical knowledge implicit in traditional culture and school mathematics.

This methodology has an additional benefit: the valorization of the traditional indigenous culture. When using traditional knowledge in mathematics education, this knowledge is valued. The valorization of culture concurrently valorizes the student and increases their self-esteem. Achieving an increase in self-confidence is fundamental to the process of learning in an intercultural context (BERNARDI; SANTOS, 2018).

Keeping these objectives in mind, we presented this analogy to math students enrolled in intercultural courses at Unochapecó. This presentation demonstrates that the students are inclined toward our analogy.

The presentation of the research was simple because it drew upon ideas that belong to the cultural universe of the students. The students easily understood the logical-mathematically complexity of our research because they were already trained in this area. Consequently, explaining the hypothesis was quite simple. They already intuitively understand the relationship between Kamé/Kairu and the lambré function, and, by extension, they were able to understand the logical and algebraic formalizations easily. Our mathematical formalization merely represents an extension of alreadypossessed knowledge.

After presenting the logical-mathematical part, we explained its translation in logical-electronic circuits. This surprised the students because their traditional thinking is linked to the new information technologies that they admire. By presenting their traditional knowledge as complex thinking, even analogous to concepts used in technology developments, the value of traditional culture is recognized. This increases the self-esteem of indigenous students in line with what is postulated by our methodology.

After the presentation, we conducted a question and answer session. In this context, one of our students who belongs to a village that strictly follows the tradition of clan halves, offered to draw his family tree.

The family tree he created supports our hypothesis (Figure 7), as it illustrates the inheritance of a binary (logic) order with which the tribe and its clans are organized. 
Figure 7 - Ancestry diagram

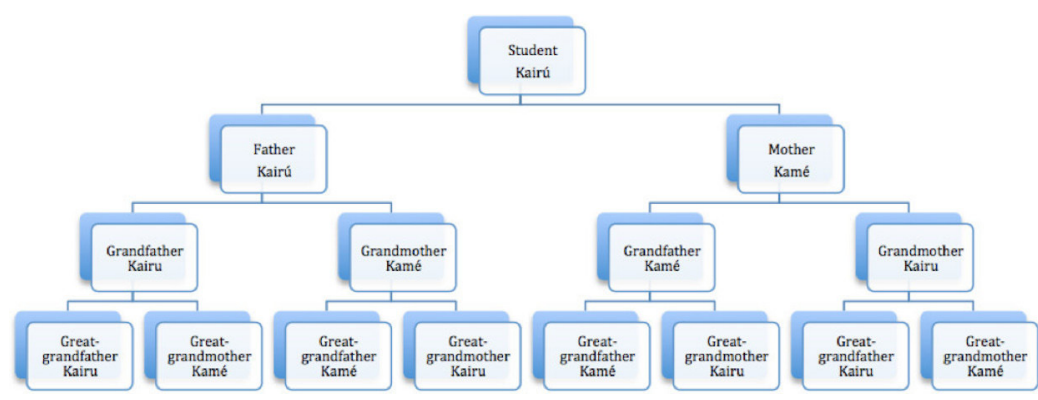

Source: Prepared by the authors.

The student's family tree exposed a binary branching schema we had not previously considered. This schema clearly shows the logical order with which the traditional Kaingang society is organized. As teachers and researchers, we were able to learn a great deal from this session.

This new analogy will serve to explain other schemes of logical and computational order. There even arose the hypothesis that the kinship system could be expressed as an algorithm.

We consider this experience to be very successful and extremely enriching. Several students expressed interest in pursuing postgraduate courses in ethno mathematics after completing their current degree. We are working with students interested in computing to develop a project to create a pedagogical program that links traditional Kaingang logic and etno mathematics with the knowledge of nonindigenous societies. Finally, we are working with Kaingang students to build a webpage to disseminate works on ethno mathematics.

\section{Conclusion}

We analyzed the analogy between the dialectical thought of Kaingang culture, and algebraic and binary logics. We can conclude that the proposed analogy has been confirmed with a high degree of plausibility. This analysis was carried out under the hypothesis that, if the analogy were to be demonstrated, it could provide interesting information for mathematical and scientific education in intercultural contexts.

In fact, we showed that it was very useful to use our hypothesis in mathematics. We were able to establish an interesting relationship between traditional knowledge and school mathematics. This relationship represents an important pedagogical tool to teach complex mathematical concepts based on the traditional wisdom of the Kaingang people.

The proposal also served to increase students' self-esteem and to increase the value to traditional culture. Our direct work with students elucidated the potential for new initiatives, hypotheses, and projects.

We believe that this analogy can go beyond the field of ethno mathematics and may be a topic of interest for other areas such as anthropology, intercultural philosophy and may even be relevant to the study of human and artificial intelligence. However, these interests exceed the limit of this article, so we will simply include them as a proposal for new research and future articles. 


\section{Acknowledgment}

This work was carried out with the support of the Coordenação de Aperfeiçoamento de Pessoal de Nível Superior (Capes), Financing Code 001.

\section{Referências}

ANHAIA, G. M. A educação matemática no processo de reafirmação e revitalização cultural dos povos Kaingang. In: BENVENUTI J.; BERGAMASCHI, M. A.; MARQUES, T. B. I. (org.). Educação indígena sob o ponto de vista de seus protagonistas. Porto Alegre: Evangraf, 2013. p. 121-140.

BERNARDI, L. S.; SANTOS, J. A. Etnomatemática y pedagogía freireana: una experiencia intercultural con la comunidad Kaingang. Zetetiké, Campinas, v. 26, n. 1, p. 147-166, 2018. DOI: https://doi.org/10.20396/zet.v26i1.8650727.

D'AMBROSIO, U. Etnomatemática: elo entre as tradições e a modernidade. Belo Horizonte: Autêntica, 2005.

LÓPES BELLO, S. E. A pesquisa em etnomatemática e a educação indígena. Zetetiké, Campinas, v. 4, n. 2, p. 97-106, 1996. Retrieved Feb. 22, 2021 from: https://periodicos.sbu.unicamp.br/ojs/ index.php/zetetike/article/view/8646742.

MAYBURY-LEWIS, D. Dialectical societies: the Ge and o Bororo of central Brazil. Cambridge: Harvard University Press, 1979.

NIMUENDAJU, C. 104 mitos indígenas nunca publicados: a redescoberta do etnólogo teutobrasileiro. Revista do Patrimônio Histórico e Artístico Nacional, Rio de Janeiro, v. 21, p. 64-111, 1986. Retrieved Feb. 22, 2021 from: https://cutt.ly/kljR0cF.

SUFIATTI, T.; BERNARDI, L. M. S.; DUARTE, C. Cestaria e a história de vida dos artesãos indígenas da terra indígena Xapecó. Revista Latinoamericana de Etnomatemática, San Juan de Pasto, v. 6, n.1, p. 67-98, 2013. Retrieved Feb. 22, 2021 from: https://revista.etnomatematica.org/index.php/ RevLatEm/article/view/56.

VEIGA, J. Organização social e cosmovisão Kaingang: uma introdução ao parentesco, casamento e nominação em uma sociedade Jê meridional. 1994. 282 f. Dissertação (Mestrado em Antropologia Social) - Instituto de Filosofia e Ciências Humanas, Universidade Estadual de Campinas, Campinas, 1994. Retrieved Feb. 22, 2021 from: https://cutt.ly/QljTiQt.

VEIGA, J. Cosmologia e práticas rituais Kaingang. 2000. 367 f. Tese (Doutorado) - Instituto de Filosofia e Ciências Humanas, Universidade Estadual de Campinas. Campinas, 2000. Retrieved Feb. 22, 2021 from: https://cutt.ly/XIjTcgx.

WIESEMANN, U. G. Dicionário Kaingang-Português, Português-Kaingang. Curitiba: Esperança, 2011. 